\title{
Effect of nitrogen on flax (Linumusit Atissimum L.) fiber yield at debre berhan area, Ethiopia
}

\begin{abstract}
A field experiment was conducted during at Debre Birhan Research Station. The experiment was laid out in randomized block design with three replication of six treatments $(0,46,69,92,115$ and $138 \mathrm{~N} \mathrm{~kg} \mathrm{ha-1).} \mathrm{Flax} \mathrm{fiber} \mathrm{was} \mathrm{rated} \mathrm{in} \mathrm{water}$ for 15 days and then after dried in shed. We comp bed and processed the fibr with prototype we made at the DBU. The result showed that all agronomic parameters were significantly correlated with nitrogen fertilizer level. The result showed that there was statistically significant response with nitrogen fertilizer rate. Agronomic parameters showed also an increasing trend to fertilizer rate levels. Increase of Nitrogen fertilizer rate increased the flax fiber length. About $58 \mathrm{~cm}$ fiber length was obtained from $138 \mathrm{~kg}$ $\mathrm{N} /$ ha fertilizer rate and the lowest was in the control treatment. Finally, we recommend that nitrogen fertilizer has great impact on flax growth, development and fiber length.
\end{abstract}

Volume 2 Issue 5 - 2018

Girma Taddese, Sintayehu Tenaye

AgriCollege/Plant Science Department, Debre Birhan University, Ethiopia

Correspondence: Girma Taddese, AgriCollege/Plant Science Department, Debre Birhan University, P.O.Box 445, Debre Birhan, Ethiopia, Email girmataddesse@gmail.com

Received: June 20,2018 | Published: October 26, 2018

\section{Introduction}

Flax (Linum usitatissimum L.) is an ancient crop grown for seed, oil and for the strong fiber produced in its stems. Flax is an annual herbaceous plant; flowers have five petals and contain up to 10 seeds. Flax grows under cool conditions, grows on clean, firm and smooth seedbed. ${ }^{1}$

Approximately 7,000 years ago, ancient Egyptians domesticated flax and wrap their mummified dead with fabrics flax. ${ }^{2}$ Dyed flax fibers were also discovered in a cave in Georgia dated to 34,000 BCE.

Berglund and Zollinger ${ }^{3}$ reported that flax grows very well on clay loams, and oilseed flax is poor competitor with weeds, when planted on wider row spacing. Applying high nitrogen rate increases vegetative growth, disease susceptibility and lodging. In contrast phosphorus and potassium are not critical for flax except in cases of extreme soil deficiency. ${ }^{4}$ More over Zinc is critical for flax growth and Zinc-deficient plants are chlorotic, and the primary terminal bud may die. ${ }^{5}$

Every part of the flax plant is at man's service; seeds provide oil for dyes, paint, cosmetics and floor coverings. The by-products of linen production are processed into a pulp used for banknotes or fiberboard. ${ }^{6}$

Flax must be uprooted to preserve the full potential of fiber of each plant. Following pulling, fiber flax must be retted to allow clean separation of the fiber from the stems. Water retting, where bundles of stems are submerged for retting by anaerobic bacteria, is one of the best but most expensive methods for separating flax fibers.

Based on Uddin and $\mathrm{Kayaker}^{7}$ assessment flax fiber is superior to other fibers, and fiber flax varieties are tall, and they are grown at very high density. The collected flax is processed with different tools to remove the woody stem core. Flax straw is a carbon-neutral fuel, and has heating value as that of coal. When paper fibers lose strength each time they are recycled, adding small amounts of flax fiber to paper pulp greatly increases the strength of recycled paper. ${ }^{8-10}$

The main component of flax, cellulose, is a natural polymer on earth. ${ }^{11}$ Flax fibers are recyclable, biodegradable and carbon positive, which flax plants absorb more carbon dioxide in the growth phase than they release during processing. ${ }^{12}$

Non-degradable composites, made from non-renewable resources are consuming oil resources. ${ }^{13}$ The bio-degradable fibers such as flax, jute and hemp are preferred, which are light weight, strong, resistant to corrosion, and have good sound and moisture absorption. ${ }^{12}$

The automotive and aerospace industries are using flax fiber to replace fiberglass in a wide range of fiber-reinforced composites, due to its high performance and light weight. Flax fiber also takes much less energy to produce than fiberglass and is biodegradable., ${ }^{2,14}$

Fiber flax cultivars produce long fiber (line fiber, in the trade) and short fiber (tow). Long fiber is spun and woven to produce very high-quality linen fabric. Linen is used to make fine clothing, sheets, tablecloths, and other household goods. Linen yarn is used to make the very finest lace. ${ }^{15}$

Short fiber generally is blended with cotton or wool and spun into yarn to make a wide variety of apparel, upholstery, and carpet fabric. ${ }^{16}$

Getting quality organic fiber is becoming a great concern to supply the growing textile industries. The rapid population increase demands quality fiber products.

This study aimed to evaluate the potential development of flax fiber and oil quality (Linum usitatissimum L.) under the influence of rates of nitrogen application.

\section{Material and methods}

\section{Description of the study area}

The research was conducted at Debre Birhan University agricultural demonstration site. The site is located between $90^{\circ} 30^{\prime} \mathrm{N}$ latitude and $39^{\circ} 38^{\prime}$ E longitudes and at an altitude of $2780 \mathrm{~m}$ above sea level. The area receives mean annual rain fall of $1045.5 \mathrm{~mm}$. The mean annual temperature is $18.61^{\circ} \mathrm{Cand}$ a minimum of $5.2^{\circ} \mathrm{C}$ with the coldest season occurring between October and January; the mean relative humidity is estimated to be $10.9 \%$ and the soil is classified as Litosols and at foot slopes Vertic Cambisols in some localities. ${ }^{17-21}$ 
The experiment was laid out in a randomized block design (RCBD) with 3 replication and 6 treatments. The plot size is $1.5 \mathrm{~m} \mathrm{X} 2 \mathrm{~m}$. The treatment will consist of $\left(0,46,69,92,115\right.$ and $\left.138 \mathrm{Nkg} \mathrm{ha}^{-1}\right)$. The flax cultivar namely Belay was the main flax variety. A distance of $0.6 \mathrm{~m}$ between plot and $0.75 \mathrm{~m}$ between block was established and seed was drilled on the row $10 \mathrm{~cm} \times 10 \mathrm{~cm}$ apart in intra row. For each agronomic parameter 10 guarded plants were taken randomly from each subplot for agronomic parameters. The recorded agronomic characters included as follows: Plant height $(\mathrm{cm}) /$ plant, Number of tillers/plant, Number of branch/plant, Branch height/plant (cm)/plan, Fresh Weight (g)/plant, Dry weight (g)/plant, Number of pod per plant or capsule.

For flax fiber length determination about 10 plants were harvested from each plot. After harvesting they were retted in water for 15 days. After drying the retted flax fiber, it was dried in shade an combed with local made tools. The clean fiber length was measurd with meter.

\section{Data analysis}

The experimental data was analyzed and summarized based on analysis of variance (ANOVA). A statistical analysis was done by using SPSS software version 20 and comparisons of means at $5 \%$ and $1 \%$ level.

\section{Results and discussion}

Flax plant has several uses mainly for fiber, oil, cloth and cooking production. It was domesticated by Ancient Egyptian to wrap up mummies nearly 7000 years ago. ${ }^{2}$ Dying flax started in the cave of Gorgia in 34000 BCE. Cool climate is favorable for flax and demands clean seed bed. ${ }^{1}$ That proves that North Shwea is also highly favorable for flax production. It is possible to cultivate falx on clay loam or silty loam soils with appropriate spacing both for oil and fiber production. ${ }^{3}$ Particulalry Debre Birhan area is suitable for flax production. Application of high nitrogen increases vegetative growth, disease suitability and lodging. ${ }^{4}$ Our research on nitrogen fertilizer rate supports supports the above statement. Phosphorus and potassium are not critical for flax except in cases of extreme soil deficiency. ${ }^{4}$ Zinc is critical for flax growth and Zinc-deficient plants are chlorotic, as a result the primary terminal bud may die..$^{5}$ In support to the above results we did not apply other fertilizers except nitrogen. We plant flax with the high density as reported by Uddin and Kayaker. ${ }^{7}$ The result showed that most of agronomic parameters correlated significantly among themselves (Table 1). However, early plant development growth did not show to different treatments.

Table I Statistical analysis

\begin{tabular}{llllll}
\hline Parameters & $\begin{array}{l}\text { Sum of } \\
\text { squares }\end{array}$ & DF & $\begin{array}{l}\text { Mean } \\
\text { square }\end{array}$ & F & Sig. \\
\hline PH*Trea & 2362.75 & 5 & 472.55 & 6.272 & 0 \\
NT*Trea & 44.39 & 5 & 8.878 & 9.966 & 0 \\
NB*Trea & 436.548 & 5 & 87.31 & 9.206 & 0 \\
BH*Trea & 437.686 & 5 & 87.537 & 4.581 & 0.001 \\
FW*Trea & 110.275 & 5 & 22.055 & 3.533 & 0.038 \\
DW*Trea & 1811.892 & 5 & 362.378 & 1.771 & 0.2 \\
FWI*Trea & 3558.598 & 5 & 711.72 & 3.522 & 0.038 \\
DWI*Trea & 281.083 & 5 & 56.217 & 4.113 & 0.027 \\
NPP*Trea & 2221.794 & 5 & 444.359 & 5.522 & 0 \\
\hline
\end{tabular}

Note: Trea, treatment; $\mathrm{PH}$, plant height $=(\mathrm{cm})$; NT, number of tillers; NB, number of branch; $\mathrm{BH}$, branch height $(\mathrm{cm})$; FW, fresh weight; DW, dry weight (g); NP, number of pod per plant or capsule
The Analysis of variances showed that plant height $(\mathrm{cm}) /$ plant, number of tillers/plant, number of branch/plant, branch height/plant $(\mathrm{cm}) /$ plant, fresh Weight $(\mathrm{g}) /$ plant, dry weight $(\mathrm{g}) /$ plant and number of pod per plant or capsule to nitrogen rate application. Generally flax plant height and branch height showed an increasing trend with nitrogen fertilizer rate (Figure 1). Similar trend was obtained for plant tillering, fresh and dry weight (Figure 2) (Figure 3). Increase of Nitrogen fertilizer rate increased the flax fiber length (Figure 4). About $58 \mathrm{~cm}$ fiber length was obtained against $138 \mathrm{~kg} \mathrm{~N} /$ ha fertgilizer ate (Figure 4) and the lowest was in the control treatment.

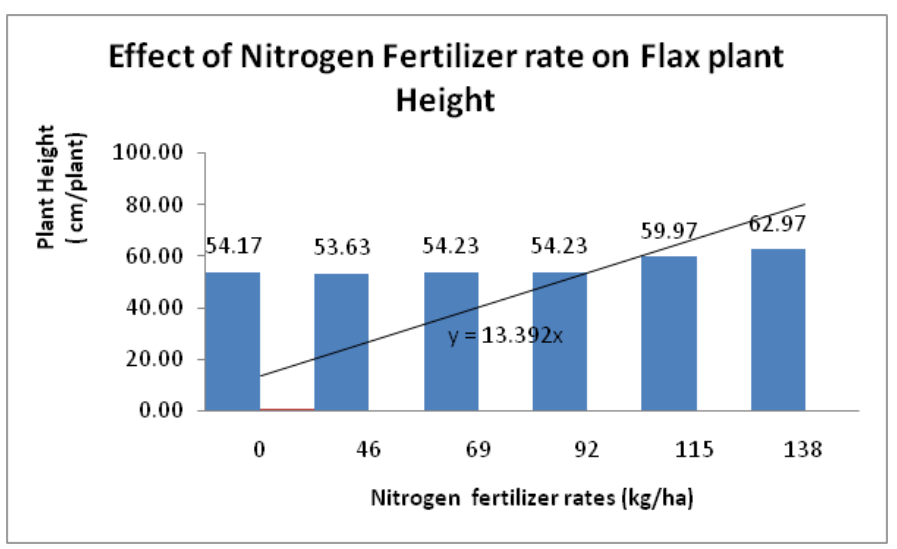

Figure I Effect if nitrogen fertilizer rate on flax plant height and branch height.

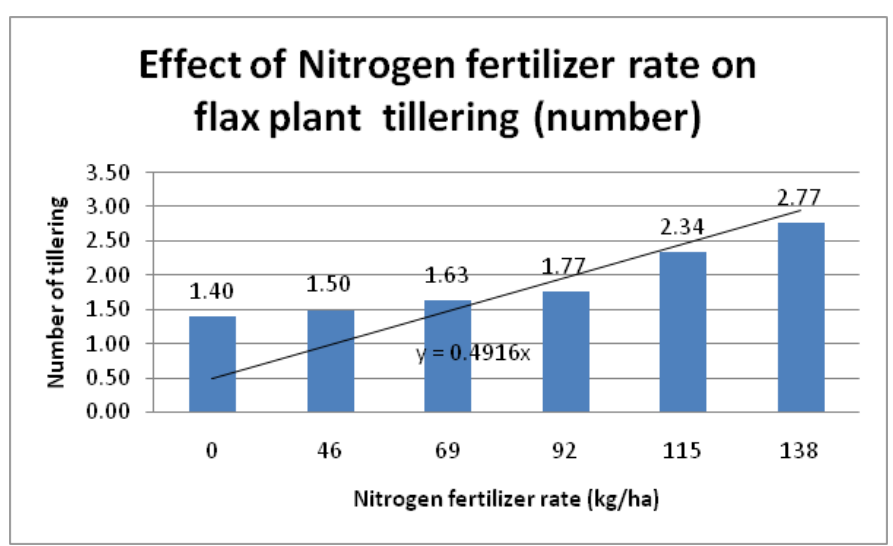

Figure 2 Effect if nitrogen fertilizer rate on flax plant tillering.

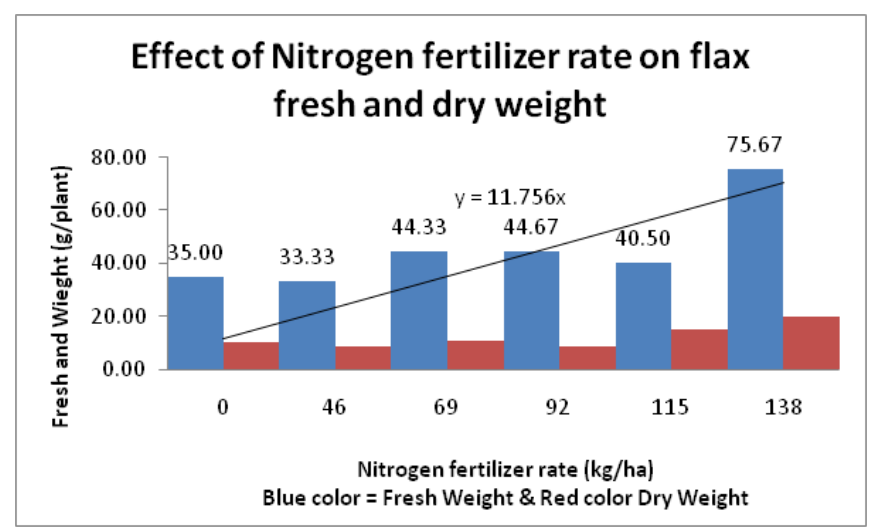

Figure 3 Effect if nitrogen fertilizer rate on flax plant fresh and dry weight. 


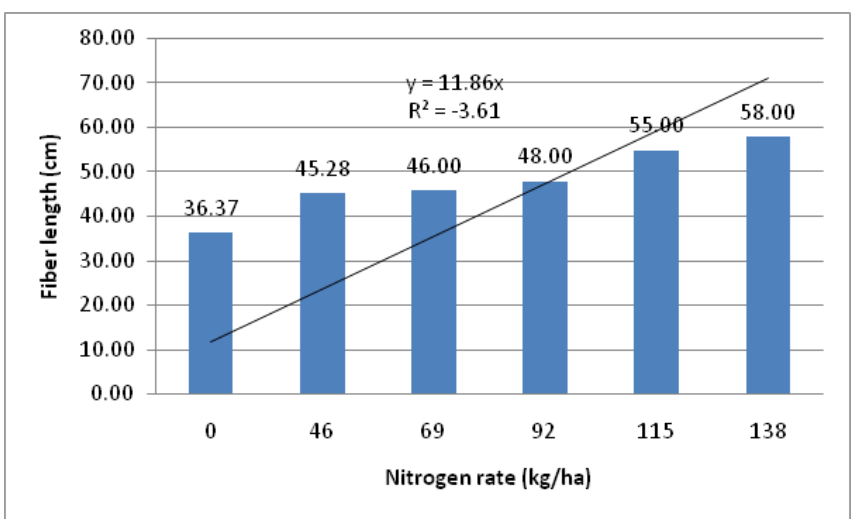

Figure 4 Influence of nitrogen rate on flax length.

\section{Conclusion and recommendation}

Flax is very important for its oil and its fiber is biodegradable which the current world demand focusing on bio-degradable material. Flax has several uses. To increase high yield of flax nitrogen fertilizer is critical. Our results supports also this there is an increase with nitrogen fertilizer rate. All measured agronomic parameters showed significant deference with nitrogen fertilizer rate. Increase of Nitrogen fertilizer rate increased the flax fiber length (Figure 4). About $58 \mathrm{~cm}$ fiber length was obtained against $138 \mathrm{~kg} \mathrm{~N} /$ ha fertgilizer ate (Figure 4) and the lowest was in the control treatment. We recommend for farmers that niting is possible in the future.

\section{Acknowledgements}

None.

\section{Conflict of interest}

Author declares that there is no conflict of interest.

\section{References}

1. Mridula D, Singh KK, Barnwal P. Development of omega-3 rich energy bar with flax seed. Journal of Food Science Technology. 2013;50(5):950957.

2. Farrer J, Finn AL. Fashion and textiles design for wellbeing: value adding through practice-led trans disciplinary design research. In: Gwilt A, editor. Fashion design for living. Routledge, Oxon; 2015. p. 25-39.

3. Berglund DR, RK Zollinger. Flax Productionin North Dakota. North Dakota State University Extension A 1038. 2002.

4. Oplinger ES, Oelke EA, Doll JD, et al. Application of natural fiber composites to musical instrument top plates. Journal Composite Material. 2012;46(2):145-54.
5. Franzen D. Fertilizing Flax. North Dakota State University; 2004.

6. Singh KK, Mridula D, Rehal J. et al. Flaxseed: a potential source of food, feed and fiber. Critical Review. Food Science Nutrition. 2011;51(3):210222.

7. Uddin N, Kalyankar RR. Manufacturing and structural feasibility of natural fiber reinforced polymeric structural insulated panels for panelized construction. International Journal Polymer Science. 2011:963549.

8. Eyres L, Eyres M. Flaxseed (linseed) fiber nutritional and culinary uses a review. Food New Zealand. 2014;14(2):26-28.

9. Carpenter JEP, Miao M, Brorens P. Deformation behavior of composites reinforced with four different linen flax yarn structures. In: Zhang D, bickering K, Gabbitas B, et al., editors. Advanced materials and processing IV. Stafa-Zurich, Switzerland: Trans Tech Publications; 2007;29-30:263-266.

10. Bos HL, Van den Oever MJA, Peters O. Tensile and compressive properties of flax fibresfor natural fibre reinforced composites. Journal of Material Science. 2000;37(8):1683-1692.

11. Liu L, Yao J. Properties of bio composite fibers from cellulose Nano whiskers and cellulose matrix. Journal Fiber Bioengineering Information. 2012;5(2):207-215.

12. Kozlowski R, Baraniecki P, Barriga-Bedoya J. Bast fibers (flax, hemp, jute, ramie, kenaf, abaca). In: Blackburn RS, editor. Biodegradable and sustainable fibers. Cambridge: Wood head Publishing Limited; 2005:3688.

13. Blackburn RS. Biodegradable and sustainable fibers. Cambridge: Wood head Publishing Limited; 2006.

14. Khalfallah M, Abbes B, Abbes F, et al. Innovative flax tapes reinforced Acrodur bio composites: a new alternative for automotive applications. Mater Des. 2014;64:116-126.

15. Summerscales J, Dissanayak NPJ, Virk AS, et al. A review of bast fibres and their composites. Part 1 fibres as reinforcements. Composites Part A. 2010;41(10):1329-35.

16. Smith M, Carlson S. Flax Production Guidelines for Iowa. 2006.

17. Hocking PJ, Randal, A Pinkerton. Mineral nutrition of linseed and fiber flax. Adv Agron. 1987;41:221-296.

18. Casa R, G Russell, B Lo Cascio, et al. Environmental effects on linseed (Linum usitatissium L.) yield and growth of flax at different stand densities. Eur J Agron. 1999;11:267-278.

19. Charlton B, Ehrensing. Fiber and oil seed flax performance. Annual report. Oregan State University, Corvalis, Oregan USA; 2001.

20. FAO. Faostat database. 2007.

21. Farrer J, Walker M. Establishing alive teaching model through funded research. BRIDGE Building Research and Innovation Deals fort he Green Economy. In: Proceedings of the Edu learn conference. Barcelona; 2014:7-9. 